\title{
気管結核を合併した下咽頭癌例
}

\author{
岩崎 幸司1) $・$ 中崎 浩一1) ・橋本 泰幸2) \\ 黒田 玲子2) ・ 種田 泉 ${ }^{3}$
}

\section{A Case of Tracheal Tuberculosis with Hypopharyngeal Carcinoma}

\author{
Koji Iwasaki and Koichi Nakazaki \\ (Hamamatsu Medical Center) \\ Yasuyuki Hashimoto and Reiko Kuroda \\ (Numazu Munincipal Hospital) \\ Izumi Oida \\ (Seirei Hamamatsu Hospital)
}

We report a case of tracheal tuberculosis with hypopharyngeal carcinoma.

A 77-year-old man complained of a right neck mass, and an open biopsy was performed. The biopsy specimens revealed a squamous cell carcinoma. At that time, laryngeal, pharyngeal, esophageal and gastric tumors were not found by fiberscopy, but chest CT revealed mediastinal lymphadenopathy. Three months later, a hypopharyngeal carcinoma, tracheal telangiectasia and tracheal granulation were found by bronchofiberscopy, and the biopsy specimen of tracheal granulation showed epithelioid cells, necrosis, lymphocytic invasion and giant cells. He was diagnosed with tracheal tuberculosis and treated with INH and RFP. Furthermore, radiotherapy was employed for the hypopharyngeal carcinoma and cervical metastasis.

A bronchoscopic examination 3 months after treatment revealed reduced tracheal granulation and no hypopharyngeal tumor or tracheal telangiectasia. However, the hypopharyngeal carcinoma recurred and the patient died due to a rupture of the carotid artery with carcinoma invasion. An autopsy showed that the tuberculous lesion had disappeared.

Key words : tracheal tuberculosis, hypopharyngeal carcinoma, bronchofiberscopy

はじめに

気管に限局した結核性病変はまれである７7歳男性が 頸部腫瘤を主訴として来院し, 生検の結果下咽頭癌頸部 転移と診断されたが， CT 上縦隔リンパ節の腫大も認め られたため，気管支鏡検査を行ったところ，気管に肉芽 腫性病変があり, 生検により気管結核を合併していると 診断され，抗結核㶡投与後内視鏡的に経過を観察しえた 症例を経験したので若干の文献的考察を加えて報告する.

\section{症例}

患者 : 77歳, 男性.

主訴 : 右頸部腫瘤.

家族歴，既往歴：特記すべき事項なし.

現病歴 : 平成 8 年 1 月中旬より右頸部腫瘤を自覚した ため近医を受診し，1月26日に当院外科を紹介され受診 した．初診時右頸部に約 $4 \times 3 \mathrm{~cm}$ の硬い腫瘤を認め, 抗生剂を投薬したが変化がないため 2 月 15 日に頸部腫瘤

1）県西部浜松医療センター耳鼻咽㗋科

2) 沼津市立病院耳鼻咽喉科

3）聖隷浜松病院耳鼻咽喉科 
の生検を施行した。病理結果は角化傾向の乏しい中分化 型扁平上皮癌(図 1 ) であり，リンパ節転移と考えられた。 胸部レントゲンは特に異常なく，3月 1 日に食道, 胃内 視鏡検査を行ったが異常は認められなかった，原発巣検 索のために 3 月 7 日に耳鼻咽喉科を紹介され受診した。 ファイバースコープでは喉頭叔よび上咽頭から下咽頭に 腫瘍等の所見は認められなかった。また 3 月 22 日の胸部 CT で縦隔 (右気管周困)のリンパ節腫大が認められたた め(図 2 ) 胸部外科を受診した、胸部原発の悪性腫瘍の可 能性が考兄られたため気管支鏡検査を勧め，頸部腫瘍に

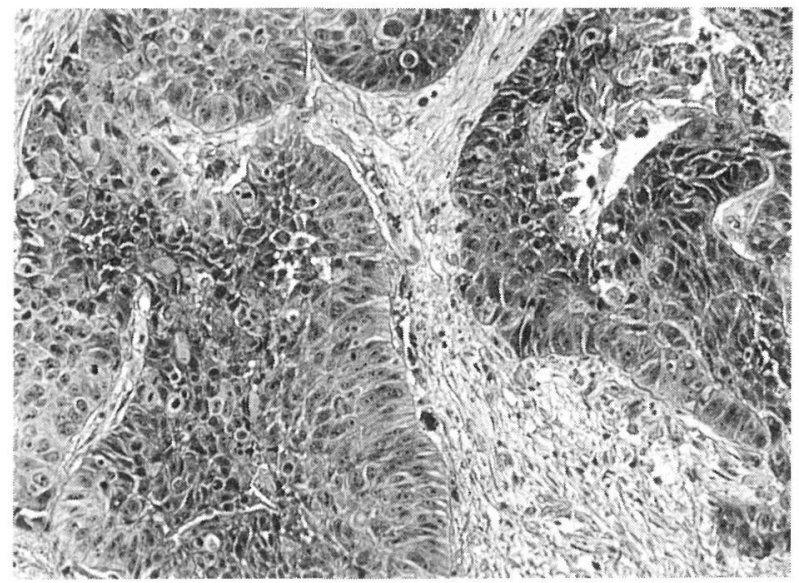

図 1 頸部リンパ節病理組織像 $(\mathrm{HE}$ 染色, $\times 20)$

角化傾向の乏しい中分化型扁平上皮癌であり，頸部リン パ節転移と考光られた。

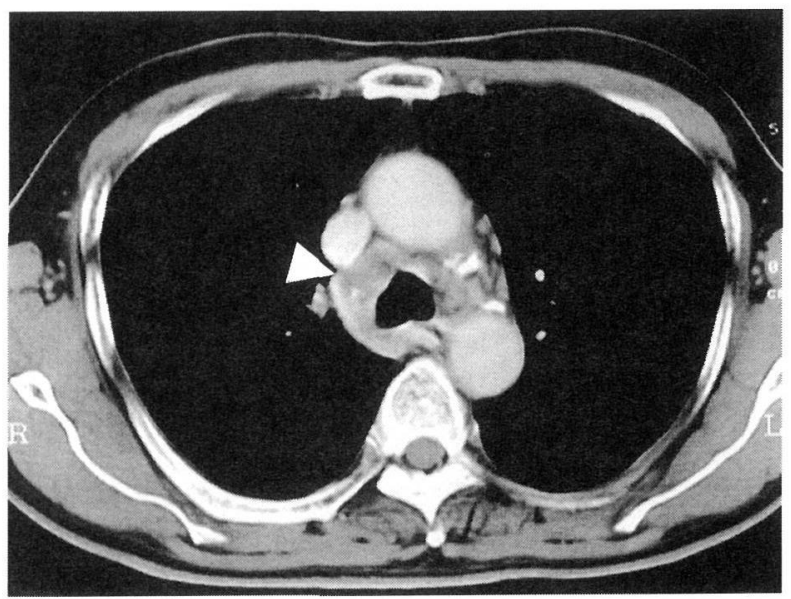

図 2 胸部 CT 像(平成 8 年 3 月 22 日) 縦隔 (右気管周囲)にリンパ節腫大が認められた $(\triangle)$.
対しても入院の上，精査・治療を锥めたが，患者は承諾 しなかった。 その後右頸部腫瘍に著変はみられなかった が，患者が気管支鏡検査を承諾したため 5 月 1 日に検査 を施行し，下咽頭右梨状陷凹に小さな腫瘍性病変が認め られ(図 3 ) 生検を行った。乙かし患者の喉頭反射が強く 気管まで内視鏡を入れることはできなかった。下咽頭腫 瘍は病理組織学的に中分化型涮平上皮癌(図 4 ) と診断さ れ，右頸部腫瘍は下咽頭癌のリンパ節転移であることが

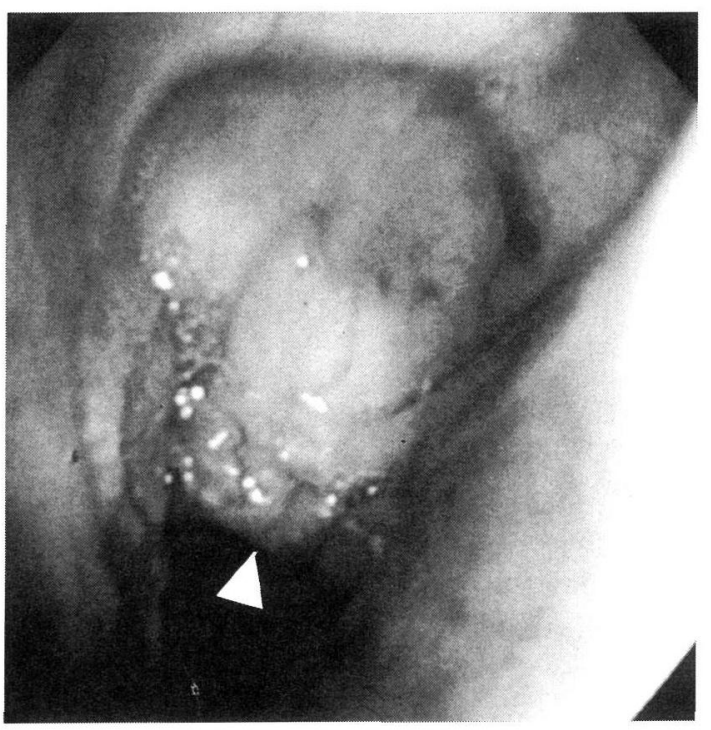

図 3 下咽頭ファイバースコープ所見(平成 8 年 5 月 1 日) 右梨状陥凹に腫瘍 $(\triangle)$ を認めた(左側が右披裂部，右側 が下咽頭後壁).

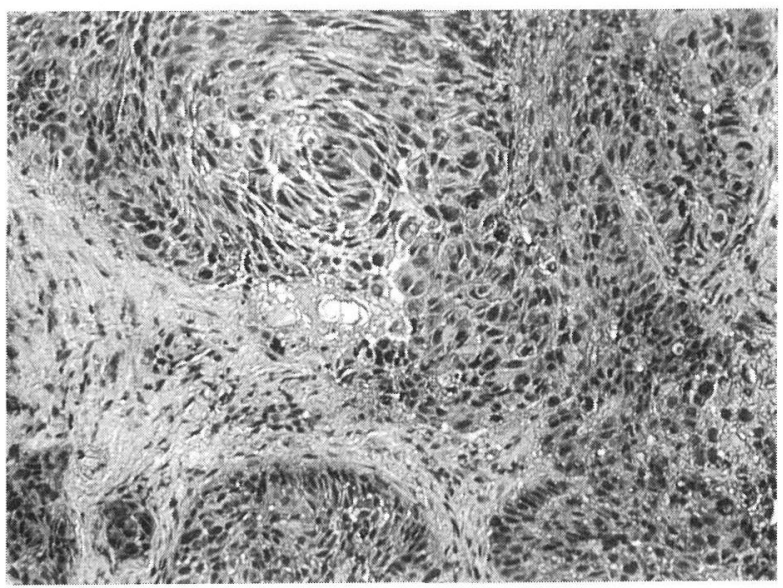

図 4 下咽頭腫瘍病理組織像 $(\mathrm{HE}$ 染色, $\times 20)$ 中分化型扁平上皮癌. 
わかった. 下咽頭癌の病期は T1N2aM0, stage NA で あったため下咽頭腫瘍切除, 頸部郭清術の適応之考㝋ら れたが，患者が手術を拒否したため，次善の策として放 射線治療拈よび再度の気管支鏡検查目的で 6 月 4 日飞入 院した。 6 月 5 日に前投薬にオピスタンを加光気管支鏡 検査を行ったところ，気管下部右壁に（第 6 気管輪から 気管分岐部にかけて)血管の拡張之気管分岐部右壁の白 色の隆起性病変を認め(図 5 ), その隆起部の生検を行っ た. 病理組織学的に類上皮細胞の増殖とリンパ球の浸潤,

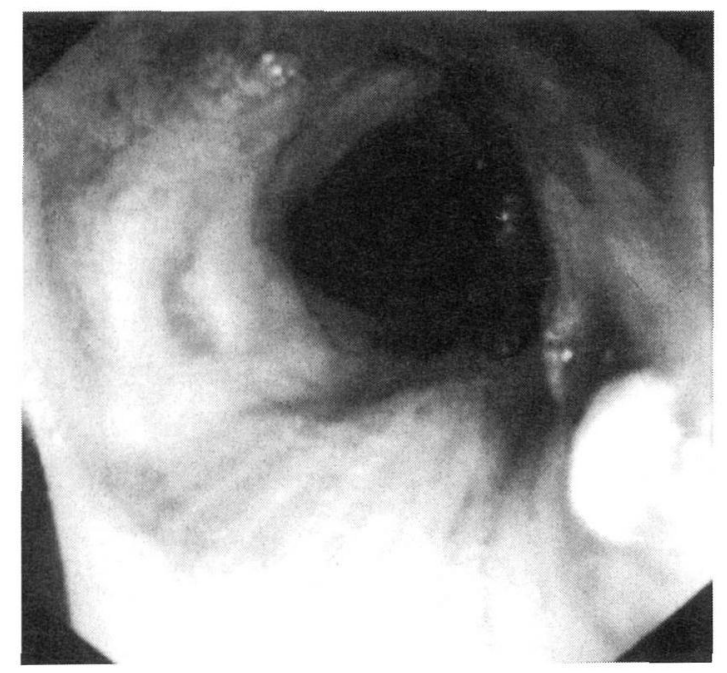

図 5 気管ファイバースコープ所見(平成 8 年 6 月 5 日) 気管分岐部右壁に白色の隆起性病变を認めた。

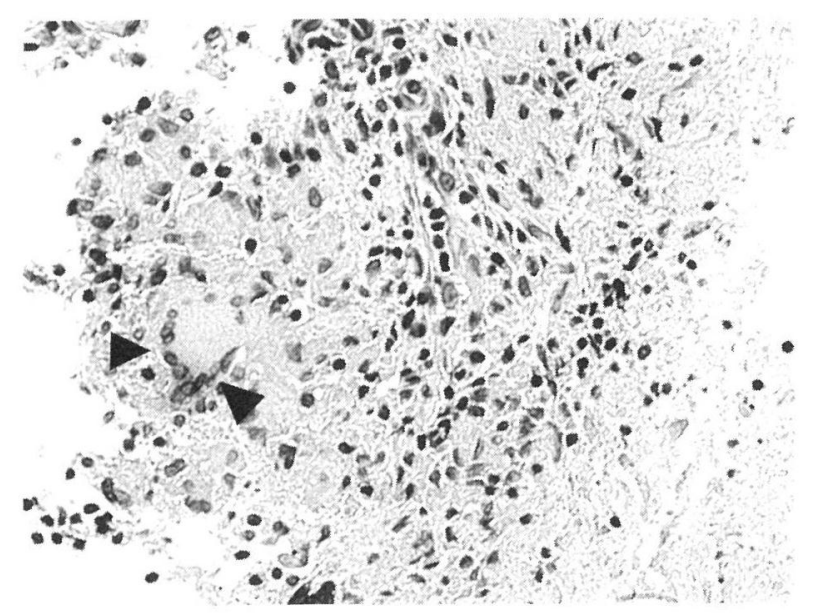

図 6 気管肉芽の病理組織像 $(\mathrm{HE}$ 染色, $\times 20)$

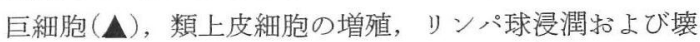
死が認められた。
一部に壞死を伴い，巨細胞が認められ(図 6 ) 結核性病変 が強く疑われた。な特，レントゲン上両側肺尖部に胸膜 の肥厚がみられたが，胸部 CT 上結核の活動性病変は認 められず，喀痰培養，PCR による結核菌検査の結果は 陰性で, 胃液の抗酸菌塗抹検查も陰性であった。 6 月 13 日のツベルクリン反応は発赤 $25 \times 19 \mathrm{~mm}$, 硬結 $8 \times 8$ $\mathrm{mm}$ と強陽性であった．以上より気管の肉芽性病変は結 核と考光，6月17日より1日量としてイソニアジド(INH) $0.4 \mathrm{~g}$ 、リファンピシン (RFP) $0.45 \mathrm{~g}$ の内服を開始した. また，6月18日より下咽頭，右頸部に 1 日 $2 \mathrm{~Gy}$ の放射 線治療を開始した。 8 月 2 日に照射量 $48 \mathrm{~Gy}$ の時点で 気管支鏡検查を行ったところ，下咽頭腫瘍は消失し，気 管下部の血管拡張像も消失し, 気管分岐部の隆起性病変 は縮小していた(図 7)。8月12日に照射量 $64 \mathrm{~Gy}$ の時 点でMRI 検查を行ったところ，下咽頭癌特よび右頸部 リンパ節腫大が消失していたため放射線治療を終了し退 院した．抗結核剤は11月まで内服を続けた。しかし，平 成 8 年11月より再び右頸部リンパ節が腫大し，11月 8 日 の気管支鏡検査で下咽頭腫瘍の再発が認められた。また 気管の肉芽があった部位は血腫様となっていた(図 8 ). 平成 9 年 1 月の胸部 CT では右気管周囲のリンパ節腫大 は消失していた(図 9)。一方, 下咽頭腫瘍再発に対して は頸部追加照射, カルボプラチンなどによる全身化学療 法を行ったが効果なく, 平成 9 年 7 月 1 日右頸動脈より

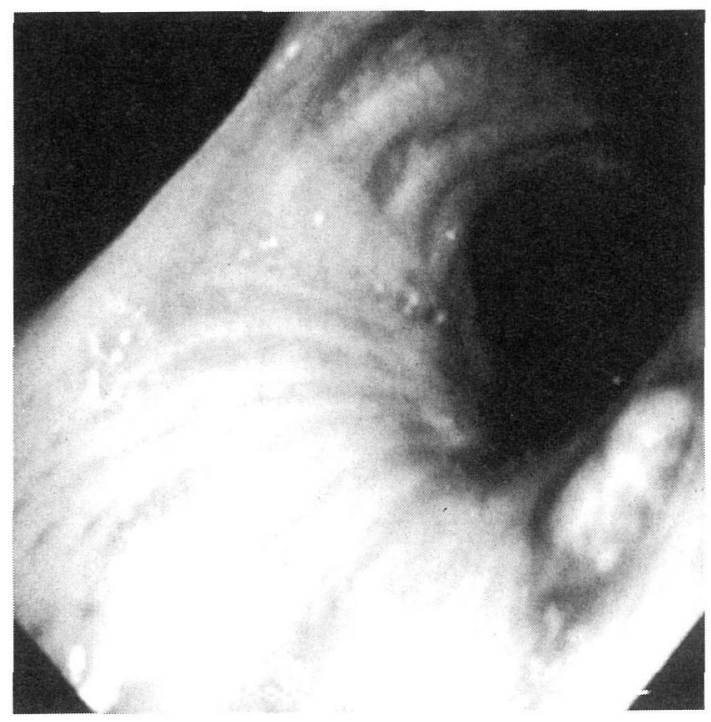

図 7 ファイバースコープ所見(平成 8 年 8 月 12 日) 気管分岐部の隆起性病変は縮小していた. 


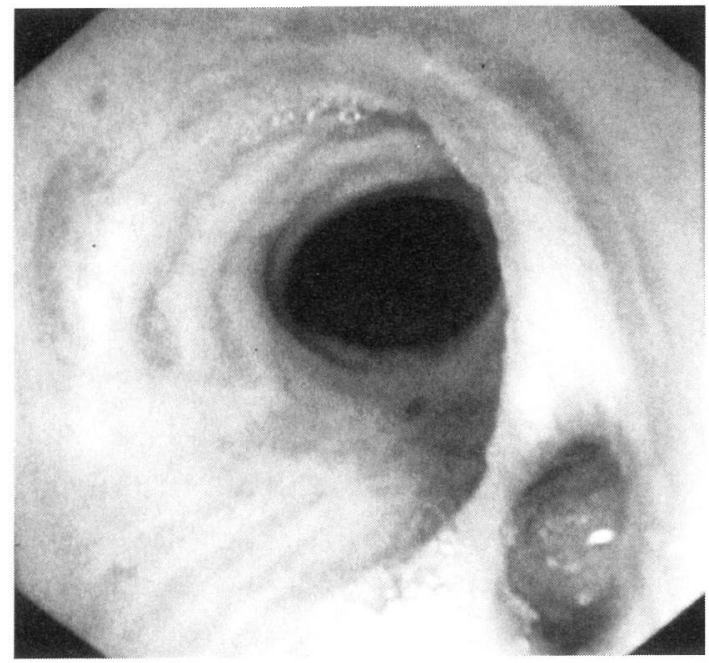

図 8 ファイバースコープ所見(平成 8 年11月 8 日)

気管分岐部の隆起性病変はさらに縮小し, 血腫様になっ ていた。

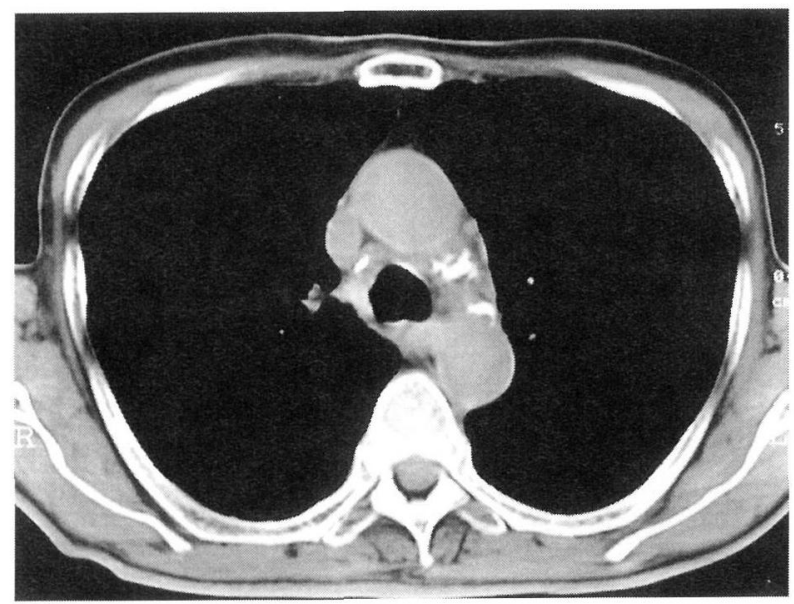

図 9 胸部 $\mathrm{CT}$ 像(平成 9 年 1 月 28 日) 縱隔 (右気管周团)のリンパ節腫大は消失していた.

の出血により死亡した．剖検の結果，死因は右頸動脈へ の腫瘍細胞浸潤による動脈破裂であった。なお，当初結 核性肉芽が認められた気管扣よび気管周团には結核性の 変化は認められなかった。

\section{考察}

結核と悪性腫瘍との関係については, 両者は共存しに くいとの説1)がありこのことが BCG による悪性腫瘍 の治療の一つの根拠となってきた2)。しかし, 悪性腫瘍
と結核の合併症例の報告も Kaplan ら³ 多数久られ(4)5), (かなる癌患者も結核の合併があり得 ると述べられている。

しかし，気管結核と頭頸部癌の合併はきわめてまれで ありわれわれが検索した限りではこのような症例はな かった。また関連する疾患として, 頸部結核性リンパ節 炎と悪性腫瘍の合併の頻度は少ないといわれて特り6), 特に頭頸部領域の癌と肺病変を伴わない頸部結核性りン 擳炎の併発は，本邦に特いては金子ら ${ }^{6)}$ 中，大石ら の数例の報告のみである.

癌患者の結核の発症因子として, 担癌患者の細胞性免 疫の低下が示唆され，本症例飞打いても胸部レントゲン 上肺尖部に胸膜の肥厚がみられたため, 初感染後発症せ ず潜んでいた結核菌が再燃した可能性が強く疑われた。 結核と癌を合併した時の治療に際する注意点として, Kaplan ら³) は癌患者へのステロイドの使用が結核の増 悪に深く関与して括り，その予後はきわめて深刻であっ たと報告している。亦た，金子らもも の使用時に制吐作用を目的としたステロイドの使用に際 して十分注意が必要であると述べている。本症例では下 咽頭癌再発後, 喉頭浮腫のためやむを兊ずステロイドを 使用したが，剖検の結果では結核の再燃は認められな かった.

一方, 肺門, 縦隔リンパ節結核は主として小児, 思春 期の結核初感染時の疾患であるが，成人に拉いても無視 し党ないことは, 古くから認識されて和り8), 最近でも 気管支結核の報告が散見されるす9 11)。 皇た最近は高齢 者の肺門リンパ節腫脤, 縱隔リンパ節腫脹のみの症例が 増加していると報告されている12)。本症例では CT で肺 門リンパ節腫大がみられたため, 気管支鏡検査による生 検によって気管結核が判明した。

$\operatorname{Im} ら^{13)}$ は23症例の縦隔リンパ節結核のCT 所見から その形態学的分析の重要性を強調し, その内部構造と造 影パターンにより４タイプに分類した. 加光て右気管気 管支リンパ節と右傍気管支リンパ節が高度に括かされる ことを他疾患との鑑別点として報告している. 本症例で も右気管気管支リンパ節が腫大して拉り，この報告に合 致している.

本症例では頸部の生検と CT などの検查から胸部腫瘍 の頸部転移が疑われたが，気管支鏡下の生検によって下 咽頭扁平上皮癌と気管結核の診断が確定した。 また, 抗 結核剤の投与後内視鏡的に気管内の経過観察をすること 
ができ，川口ら ${ }^{9}$ が述べているよらに気管支鏡の意義が 再認識された。

食道・胃内視鏡検查時や耳鼻咽喉科初診時のファイ バースコープによる検査で下咽頭腫瘍が発見できなかっ た理由としては, 患者の咽頭喉頭反射が強かったこと, 腫瘍が梨状陥凹下部の小さな病変であったこと，胸部 CT で縱隔リンパ節の腫大が認められたため検者が胸部 に原疾患があるのではないかとの先入観を持ち，また食 道・胃内視鏡検查で異常がないことがすでにわかってい たため下咽頭・食道造影検査などを行わなかったことな どが挙げられ，反省すべき点であった。

また気管に限局した結核性病変はまれであるが，縦隔 (気管周囲)のリンパ節腫大を認めたら，胸部レントゲン やCTで活動性の結核病変が認められなくても気管結核 を鑑別するために，積極的に気管支鏡検査を行うべきで あると考兄られた。

$$
\text { まとめ }
$$

77歳男性の気管結核と下咽頭癌を合併した症例を経験 したので，きわめてまれな例として報告した。また，抗 結核剂投与後の気管結核の病変の状態を内視鏡的に経過 観察することができた.

縱隔 (気管周囲)のリンパ節腫大を認めた場合, 胸部レ ントゲンやCTで活動性の結核病変が認められなくても 気管結核を鑑別するために，積極的に気管支鏡検查を行

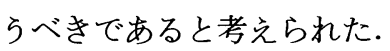

稿を終えるにあたり御校閲いただいた，県西部浜松医療セン タ一胸部外科の半澤 鹪先生, 病理科の小澤享史先生に深謝い たします。

なお，本論文の要旨は第60回耳鼻咽喉科臨床学会 (1998年, 岡山)に拈いて発表した.

\section{参考文献}

1) Watoson WL : Lung Cancer. pp 8, Mosby, Saint Louis, 1968.

2 ) 中村憲二, 李 龍彦, 中元賢武, 他 : 肺結核病棟に打ける 肺癌. 結核 $56:$ 403 406, 1981.

3 ) Kaplan MH, Armstrong D and Rosen P : Tuberculosis complicating neoplastic disease; a review of 201 cases. Cancer $33:$ 850 858, 1974.

4 ) Feld R, Bodey GP and Groschel D : Mycobacteriosis in patients with malignant disease. Arch Intern Med 136 : $67 \sim 70,1976$.

5 ) 福重潤一郎, 丸山孝一, 川上 浩, 他 : 悪性腫瘍患者の結 核症. 癌の臨床 $32: 234 \sim 240,1986$.

6 ）金子卓爾, 赤尾一郎, 岩武博也, 他：上咽頭癌と頸部結核 性リンパ節炎の合併症例. 耳鼻臨床 $89: 495 \sim 499,1996$.

7 ）大石公子, 鵜飼幸太郎, 坂倉康夫, 他 : 当教室 12 年間の頸 部リンパ節結核の臨床統計的観察. 耳鼻臨床 $79: 609 \sim$ $616,1986$.

8 ) Cohen AG and Wessler $\mathrm{H}$ : Clinical recognition of tuberculosis of the major bronchi. Arch Intern Med $63: 1132$ $\sim 1157,1938$.

9 ）川口真平, 小林英夫, 桐生拓司, 他: 内視鏡的に経過を観 察しえた気管支, 縦隔リンパ節結核の 1 例. 気管支学 16 : $582 \sim 586,1994$.

10）野村 敏, 藤田岳史, 有吉 功, 他: 肺野孤立性結節性陰 影を呈した気管支結核の 1 例. 気管支学 15:487〜 493, 1993.

11）野村友清, 荒井他嘉司, 稲垣敬三, 他 : 軟骨片を喀出した 気管支結核の 1 手術例. 気管支学 $16: 587 \sim 590,1994$.

12) 尾形英雄, 岩井和郎 : 最近の肺門リンパ節結核. 結核 66 : $67 \sim 74,1991$.

13) Im JG, Song KS, Kang HS, et al : Mediastinal tuberculous lymphadenitis ; CT manifestations. Radiology $164: 115$ $\sim 119,1987$.

$$
\left(\begin{array}{l}
\text { 原稿受付 : 平成 } 10 \text { 年 } 7 \text { 月 } 30 \text { 日 } \\
\text { 原稿採択 : 平成 } 12 \text { 年 } 2 \text { 月 } 9 \text { 日 } \\
\text { 別刷請求先 : 岩崎幸司 } \\
\text { † } 432-8580 \text { 浜松市富塚町 } 328 \\
\text { 県西部浜松医療センター耳鼻咽喉科 }
\end{array}\right)
$$

